Northwestern University School of Law Northwestern University School of Law Scholarly Commons

Faculty Working Papers

2010

\title{
Israel's Air Strike upon the Iraqi Nuclear Reactor
}

Anthony D'Amato

Northwestern University School of Law, a-damato@law.northwestern.edu

\section{Repository Citation}

D'Amato, Anthony, "Israel's Air Strike upon the Iraqi Nuclear Reactor" (2010). Faculty Working Papers. Paper 76.

http://scholarlycommons.law.northwestern.edu/facultyworkingpapers/76 
Israel's Air Strike upon the Iraqi Nuclear Reactor; Editorial Comment, by Anthony D’Amato*, 77 American Journal of International Law, pp. 584-588 (1983)

Abstract: The destructive potential of nuclear weapons is so enormous as to call into question any and all received rules of international law regarding the trans-boundary use of force. Many of the old rationales for these rules no longer apply. At the same time, the shared values underlying the rules apply more emphatically than ever, for the stake is global survival. I have tried to suggest some of the questions that must be asked about as apparently "simple" an incident as the Israeli attack on the nuclear reactor in Iraq.

Tags: Iraqi nuclear reactor, Israel’s aerial strike, air strike, transboundary force, anticipatory self-defense

[pg584]** It is curious that no commentary has appeared in this Journal regarding Israel's aerial strike upon the Iraqi nuclear reactor near Baghdad on the morning of June 7, 1981. Perhaps scholarly consensus accords simply with the Security Council resolution of June 19, 1981, which "strongly condemns the military attack by Israel in clear violation of the Charter of the United Nations and the norms of international conduct."FN1 My limited purpose here is to suggest questions regarding any such simple conclusion, and to invite detailed and considered scholarly analysis of the situation.FN2

The starting point for any legal analysis is Article 2(4) of the Charter.FN3 Was Israel's unannounced, premeditated aerial bombardment of the Iraqi reactor a "use of force against the territorial integrity or political independence” of Iraq? On what Professor Julius Stone has called the "extreme" view of 2(4), any unilateral employment of transboundary force not in self-defense against [pg585] an armed attack (Article 51) violates 2(4).FN4 But as Stone goes on to argue, this reading - though it commands some support in the travaux preparatoires-ignores the terms “territorial integrity” and “political independence.” FN5

I suggest that it is open to serious question whether Israel's strike was a use of force against either Iraq's territorial integrity or its political independence. No portion of Iraq's territory was taken away from Iraq by the bombardment. A use of the territory-namely, to construct a nuclear reactor-was interfered with, but the territory itself remained integral. Nor was Iraq's political independence compromised. Iraq's power was undoubtedly lessened, but in what sense was its governmental authority vis-a-vis other sovereign governments diminished? Of course, if Israel's attack had been preliminary to a military campaign directed against Iraq's territorial integrity or political independence, a purposive interpretation of Article 2(4) would result in a finding of illegality of the initial strike against the nuclear reactor. But there has been no evidence of any Israeli purpose beyond the limited one of destroying the nuclear reactor itself. In this respect, Israel's action was analogous to a limited "humanitarian intervention," such as the Entebbe raid,FN6 which can be justified along similar lines as not violative of 2(4).FN7

But there is another component to Article 2(4) - that the use of force must not be “inconsistent with the Purposes of the United Nations.” Here a purposive, or teleological, inquiry is explicitly mandated. McDougal and Feliciano, although addressing themselves to self-defense under the Charter, suggest three relevant factors for determining the objectives of the claimant (here, Israel): extension or conservation, degree of consequentiality, and exclusivity or inclusivity.FN8 Let us examine briefly the relevant questions under these categorical factors. 
As McDougal and Feliciano put it, the question of extension or conservation of values is whether Israel intended to conserve its own values rather than extend them "through acquiring or destroying values held by the opposing participant [Iraq]."FN9 In one sense, Israel's action was profoundly conservative: to check possible nuclear proliferation to a regime perceived as unstable or irresponsible. However, having its own nuclear reactor was clearly a value for Iraq. Was Israel's action "therapeutic" in McDougal's viewFN10 - to remove an enemy's potential for aggression? The difficulty of answering this question leads to McDougal's qualification that a "therapeutic" attack should be "exercisable only by, or under an unambiguous authorization from, the entire community."FN11 Yet this qualification is clearly too strong; it swamps [pg586] McDougal's own factor for analytical purposes. For it is often politically expedient for the community to condemn a forceful initiative in explicit terms, yet to approve of it in fact by stopping short of reprisals against the initiator. There is a subtle interplay of politics and acquiescence that renders any demand for "unambiguous authorization" unrealistic. The very resolution condemning Israel's aerial strike fell noticeably short of imposing any penalty or sanction against Israel.FN12

With respect to the degree of consequentiality of the values asserted by Israel, there is hardly a more fundamentally important value than the preservation of the lives of the inhabitants of the claimant state. If Iraq were to develop a nuclear weapons capability, the existence of a small state such as Israel would be in jeopardy. In other words, Israel may have been justified in attacking a nuclear reactor in Iraq, where it would not have been justified in attacking a plant that manufactured tanks or conventional artillery, because of the enormous destructive potential of nuclear weapons. Does not any consequentialist perspective require drawing a qualitative line between conventional and nuclear capabilities insofar as an interpretation of Article 2(4) is concerned?

The third factor suggested by McDougal and Feliciano is the exclusivity or inclusivity of Israel's objectives. Professor Thomas Mallison and Ms. Sally Mallison cite the following statement by Prime Minister Begin of Israel in support of their contention that Israel appeared to have acted solely for its own perceived values: "I don't care about the Arab world. I care about our lives."FN13 Yet can Begin's statement fairly be read as ruling out any other motivation? Even if it could, is it not possible that a state acting for its own interests could still be carrying out inclusive community interests? If so, what are those interests, and how do they relate to the purposes of the United Nations?

One of the purposes of the United Nations, stated to be a proper concern of the General Assembly, is "disarmament and the regulation of armaments" (Article 11). Armaments are again mentioned in the responsibilities of the Security Council: to "promote the establishment and maintenance of international peace and security with the least diversion for armaments" (Article 26). Apart from the Charter itself, it is clear that the proliferation of nuclear weapons constitutes one of the gravest threats that has ever faced mankind. Given the fact that nuclear weapons cannot be dis-invented, international stability is compromised each time a new government acquires them. The confusion and chaos that would inevitably accompany any aggressive use of nuclear weapons might rapidly escalate into an unintended war of human extinction. Although Israel's unilateral, military, and self-interested aerial attack [pg587] on the Iraqi reactor is hardly a peaceful or desirable precedent for the purposes of nonproliferation, it is possible to surmise 
that the community of nations breathed a little easier after the deed was done. At the time of the attack, Iraq was engaged in a premeditated war of aggression against its neighbor Iran.FN14 Is it not arguable that Israel was acting on behalf of inclusive community values in frustrating Iraq's desire for its own nuclear capability?

To be sure, at least two contentions can be made against the claim that Israel was acting on behalf of inclusive interests. First, one might argue that Israel acted simply to preserve its own nuclear hegemony in the Middle East, and thus retain its aggressive posture against its Arab neighbors. However, this argument, even if true, simply restates the position that Israel acted out of self-interest; it does not defeat the claim that such action served to promote inclusive interests.

Second, Iraq is a party to the Non-Proliferation TreatyFN15 and has had its nuclear installations inspected on a regular basis by the International Atomic Energy Agency, whereas Israel has refused to place its own nuclear facilities under IAEA safeguards. FN16 May we conclude that Iraq's nuclear reactor was in compliance with Iraq's "inalienable right . . . to develop research, production and use of nuclear energy for peaceful purposes," as stated in Article IV of the NPT? The question, of course, is whether IAEA inspection of the facility will continue to be frequent and thorough enough to prevent diversion of fissionable material produced by the reactor to military uses. Clearly, Israel was not convinced. Indeed, is it unreasonable to think that Iraq, or any nation building a nuclear reactor under IAEA safeguards, may at some point bar the inspection team and announce to the world that it has successfully transferred its fissionable material to its weapons program? What is to prevent clandestine transfer at times when the IAEA inspection team is not present or its attention is diverted? Finally, the building of an indigenous nuclear reactor is of inestimable educational value to government scientists who may be sharpening their expertise for the purpose of developing nuclear weaponry. These considerations suggest that the "right" to develop nuclear energy "for peaceful purposes" may be self-defeating, and that Israel's action may be the precursor of a wholesale revaluation of the NPT and the IAEA program. But even if no such revaluation takes place, is it not clear that there is at least a substantial basis for Israel's frontal challenge to the NPT-IAEA system?

I have not dealt with Israel's own purported legal justification for its aerial strike: anticipatory self-defense.[FN17] How can this be reconciled with Article 51 [pg588] of the Charter, which only allows self-defense "if an armed attack occurs"?FN18 There were claims at the time of the Cuban missile crisis of 1962 that the United States quarantine was similarly based upon Article 51 FN19 but neither have those claimants in 1962 nor has Israel in 1981 convincingly shown that such a reading of Article 51 would not render it meaningless and in fact open the door to aggression. In particular, we may anticipate that someday tensions between the Soviet Union and the United States may be so high that the only security either nation will have against a war of annihilation will be the clear legal rule prohibiting anticipatory self-defense. FN20

The destructive potential of nuclear weapons is so enormous as to call into question any and all received rules of international law regarding the trans-boundary use of force. Many of the old rationales for these rules no longer apply. At the same time, the shared values underlying the rules apply more emphatically than ever, for the stake is global survival. I have tried to suggest 
some of the questions that must be asked about as apparently "simple" an incident as the Israeli attack on the nuclear reactor in Iraq. I have also made assertions that, if not convincing, I hope may have heuristic value. I would welcome debate on this question, and analysis in more detail than the sketchy overview given here.

\section{Footnotes}

*Copyright (c) 1983 by the American Society of International Law; Anthony D'Amato

**Numbers in the format pg584 etc. refer to the paging in the original article.

FN1. UNSC Res. 487, 36 UN SCOR (2288th mtg.), UN Doc. S/RES/487 (1981), reprinted in 75 AJIL 724 (1981).

FN2. See Mallison \& Mallison, The Israeli Aerial Attack of June 7, 1981, Upon the Iraqi Nuclear Reactor: Aggression or Self-Defense?, 15 VAND. J. TRANSNAT'L L. 417 (1982). At the time of the attack, I took the position that the Israeli action was legal under international law, but that Israel owed monetary compensation to Iraq for the actual damage to the nuclear facility and for the four lives that were lost. The Israeli Air Strike: Hearings Before the Senate Comm. on Foreign Relations, 97th Cong., 1st Sess. 85-88 (1981).

FN3. Article 2(4) provides: “All Members shall refrain in their international relations from the threat or use of force against the territorial integrity or political independence of any state, or in any other manner inconsistent with the Purposes of the United Nations.”

FN4. J. StOne, AgGression ANd World ORder 95 (1958).

FN5. Id. at 97-100. See, e.g., Franck, Who Killed Article 2(4)?, 64 AJIL 809 (1970); Henkin, The Reports of the Death of Article 2(4) Are Greatly Exaggerated, 65 AJIL 544 (1971).

FN6. See Boyle, International Law in Time of Crisis: From the Entebbe Raid to the Hostages Convention, 75 Nw. L. REV. 769 (1980).

FN7. See, e.g., Lillich, Humanitarian Intervention: A Reply to Ian Brownlie and a Plea for Constructive Alternatives, in LAW AND CIVIL WAR IN THE MODERN WORLD 229 (Moore ed. 1974). Contra, Brownlie, Humanitarian Intervention, in id. at 217.

FN8. M. McDougal \& F. Feliciano, LAW And Minimum World Public Order 222 (1961).

FN9. Ibid.

FN10. Id. at 223.

FN11. Id. at 224.

FN12. Supra note 1. The lack of imposition of a sanction, penalty, or reprisal of any kind, whether from the United Nations or any individual nation, tends to support a claim that the act complained of was in fact legal. See D'Amato, The Concept of Human Rights in International 
Law, 82 Colum. L. Rev. 1110, 1118-22 (1982); Reisman, Sanctions and Enforcement, in The FUTURE OF THE INTERNATIONAL LEGAL ORDER 273 (Black \& Falk eds. 1971).

FN13. Mallison \& Mallison, supra note 2, at 426 (quoting Washington Post, June 9, 1981, at A11, col. 1).

FN14. See Falk, Some Thoughts on the Decline of International Law and Future Prospects, 9 HOFSTRA L. REV. 399 (1981).

FN15. Treaty on the Non-Proliferation of Nuclear Weapons, 21 UST 483, TIAS No. 6839, 729 UNTS 161 (July 1, 1968), reprinted in 7 ILM 811 (1968).

FN16. Mallison \& Mallison, supra note 2, at 440-41. The Mallisons argue that by joining the NPT and opening its own nuclear installations to IAEA inspection, Israel would gain leverage over the adequacy of IAEA supervision: "It would have at least been difficult, and probably impossible, for Iraq to refuse additional international inspection had Israel agreed to the same inspection for itself." Id. at 428. How can it be "impossible” for a nation to refuse something?

FN17. See id. at 435-37.

FN18. The argument that there is an inherent right of self-defense apart from the limitation ("if an armed attack occurs") of Article 51 is, according to Professor Henkin, "unfounded, its reasoning is fallacious, its doctrine pernicious.” L. HeNKIN, How NATIONS BEHAVE 141 (2d ed. 1979).

FN19. The Mallisons, supra note 2 at 423-24, do not convincingly distinguish the Cuban missile crisis from the Israeli aerial strike of 1981. Previously, Professor Mallison had written that the American position in 1962 was justified as self-defense under Article 51. See Mallison, Limited Naval Blockade or Quarantine Interdiction: National or Collective Defense Claims Valid Under International Law, 31 GEO. WASH. L. REV. 335 (1962). President Kennedy himself carefully refrained from invoking Article 51 in support of the American quarantine, but he did use the language "in support of our own security” in his address of Oct. 22, 1962, 47 DEP'T STATE BULL. 716 (1962), and "to defend the security of the United States" in his Proclamation No. 3504 of Oct. 23, 1962, id. at 717,27 Fed. Reg. 10,401 (1962). See also Wright, The Cuban Quarantine, 57 AJIL 546, 560 n.53 (1963); MacChesney, The Quarantine Against Cuba: Legal or Illegal?, id. at 588, 589-90.

FN20. See Henkin, The United Nations and Its Supporters: A Self-Examination, 78 PoL. ScI. Q. 504, 532-33 (1963). 